\title{
Business models for the circular economy: opportunities and challenges.
}

\section{FRACCASCIA, L., GIANNOCCARO, I., AGARWAL, A., HANSEN, E.G.}

This is the peer reviewed version of the following article: FRACCASCIA, L., GIANNOCCARO, I., AGARWAL, A. and HANSEN, E.G. 2019. Business models for the circular economy: opporCtunities and challenges. Business Strategy and the Environment, 28(2), pages 430-432, which has been published in final form at https://doi.org/10.1002/bse.2285. This article may be used for non-commercial purposes in accordance with Wiley Terms and Conditions for Use of Self-Archived Versions. 


\section{Business Strategy and the Environment (BSE) \\ SPECIAL ISSUE - CALL FOR PAPERS}

\section{Business Models for the Circular Economy: Opportunities and Challenges}

Submission Deadline: 30th August 2019

Guest Editors: Luca Fraccascia ${ }^{1,2}$, Ilaria Giannoccaro ${ }^{3}$, Abhishek Agarwal ${ }^{4}$, Erik G. Hansen ${ }^{5}$

${ }^{1}$ Department of Computer, Control, and Management Engineering “Antonio Ruberti”, Sapienza

University of Rome (Italy) - luca.fraccascia@uniroma1.it

${ }^{2}$ Department of Industrial Engineering and Business Information Systems, University of Twente (The Netherlands)

${ }^{3}$ Department of Mechanics, Mathematics, and Management, Polytechnic University of Bari (Italy) ilaria.giannoccaro@poliba.it

${ }^{4}$ Department of Management, Aberdeen Business School, Robert Gordon University (UK) a.agarwal@rgu.ac.uk

${ }^{5}$ Institute for Integrated Quality Design (IQD), Johannes Kepler University Linz (Austria) erik.hansen@jku.at

The circular economy is receiving increasing attention as a way to overcome the linear economic model, which is characterized by a "take-make-dispose" pattern. The circular economy aims at slowing (i.e., maintenance, repair, remanufacturing) and closing (i.e., recycling) resource cycles (Bocken et al., 2017; Stahel and Reday-Mulvey, 1981) in order to obtain sustainable development leading to reduced amounts of natural resources used, wastes disposed of in landfills, and greenhouse gas emitted to the atmosphere (e.g., Ghisellini et al., 2016; Kirchherr et al., 2017; Korhonen et al., 2018). In this scenario, companies and policymakers are called to design and implement circular economy strategies.

A recent business concept, developed in the literature to advance circular strategies, is the business model (Bocken et al., 2016). The business model concept first advanced in the strategic and innovation management literature and refers to the conceptual logic of how firms create and appropriate economic value (Richardson, 2008). Linked to sustainability (Stubbs and Cocklin, 2008) and advanced towards "business models for sustainability” (Boons and Lüdeke-Freund, 2013; Schaltegger et al., 2016a) they are understood to "create competitive advantage through superior customer value and contribute to a sustainable development of the company and society" (Lüdeke-Freund, 2010, p. 23) (see also Bocken et al., 2014; Boons and Lüdeke-Freund, 2013; Lüdeke-Freund et al., 2018a; Schaltegger et al., 2012, 2016b, 2016a). Business models for circularity (BMCs) can be considered a subset of this broader 
category. They explicitly link the business model to the product life-cycle (Hansen et al., 2009) and are a vehicle to slow and/or close (additionally also narrowing) resource cycles (Bocken et al., 2017, 2016).

While the link between product life-cycle management and business model innovation was established early on (e.g., Hansen et al., 2009), few studies on BMCs have been undertaken to date. Many of the works are of a conceptual nature, aimed at developing taxonomies or typologies (Bocken et al., 2016; Lewandowski and Mateusz, 2016; Lüdeke-Freund et al., 2018b). In this regard, the lack of case studies, as well as other empirical evidence, makes it challenging to understand how companies can design and implement BMCs (Evans et al., 2017). Furthermore, the proposed contributions usually adopt the perspective of the single company, which is borrowed from the traditional business model literature, and focuses on the idea that the boundaries of the business model coincide with the boundaries of the firm (Evans et al., 2017). This is problematic because integrating sustainability and circularity into business models requires a systemic view covering entire value networks and the consideration of different elements of the system and their interrelations (e.g., Zucchella and Previtali, 2018).

Against this background, there is the need to investigate how companies can further develop their current business from the perspective and through adoption of BMCs; how they can identify and manage risks stemming from implementing these models (e.g. cannibalization of circular and conventional business); and how policymakers can support the design and adoption of BMCs at company, industrial ecosystem, and societal levels. Furthermore, it is important to study how the adoption of BMCs might impact on traditional production and supply chains. Finally, from the methodological point of view, further investigation is required to design methods and metrics for assessing the environmental and social sustainability impacts of BMCs (e.g., de Jesus and Mendonça, 2018; Evans et al., 2017; Perey et al., 2018).

This special issue aims at collecting original and high-quality studies on how business models inform the perspective of the circular economy. We seek works that analyze BMCs at the level of individual managers (and their decisions), single companies, value networks, and industrial ecosystems. Particularly welcome are economic, management, and sustainability theories and applications that specifically address the current challenges of designing, implementing, and diffusing BMCs. We are also interested in bridging the gap between and integrating other relevant fields (e.g., supply chain management, digitalization, innovation, marketing / commercialization). We are open to all methods including qualitative, quantitative, and mixed-methods and also seek conceptual, theoretical, and literature review papers if they advance the field in significant ways.

Topics of interest in this special issue include, but are not limited to, the following: 
- Organizational and individual aspects of BMCs:

o How companies can integrate and/or coordinate new BMCs with their current business models and related cannibalization

o Business models for addressing different circular strategies (maintenance, repair, remanufacturing, recycling) in different industries

o Managing risks in BMCs

o Business models innovation in the context of cradle-to-cradle certified products/organizations

o Individuals' mental frames, decision making, and sense-making within BMCs

o The role of use-oriented (e.g. rental, leasing) and performance-oriented (e.g. pay-peruse) product-service systems for BMCs

o Decoupling of BMC strategies and (actual) operations

o What we can learn from the rediscovery of declining BMCs such as returnable bottles, shoemakers, and tailors

- Interorganizational, life-cycle, and cross-sector aspects of BMCs:

o BMCs for industrial ecosystems and supply chains

o Business models for eco-industrial parks and industrial symbiosis

o Impact of BMCs on traditional production and supply chains

o Cross-sector business models for secondary resource retrieval and use

o The role of public sector in supporting BMCs

- The customer interface of BMCs:

o Consumer acceptance of BMCs

o Business model redesign for successful product take-back

o Linking business models, the Internet of Things (e.g. smart products), and circularity

- Impacts of BMCs:

o Environmental and social contributions of BMCs

o Methods, metrics, and performance management for assessing the sustainability of a BMC

o BMCs in developing countries

\section{Submission Process and Deadlines:}

- Submissions should be prepared using the BSE Author Guidelines, available via https://onlinelibrary.wiley.com/page/journal/10990836/homepage/forauthors.html

- Manuscripts should be written in English, between 6,000-8,000 words in length

- Manuscripts should be submitted by e-mail to Luca Fraccascia at luca.fraccascia@uniroma1.it with the subject: "Special Issue BMC" - and last name of the first author. 
- Papers will be reviewed according to the BSE double-blind refereed process

- Any queries relating to the Special Issue, proposed topics and potential fit to the Special Issue should be directed to guest editors.

$\begin{array}{ll}\text { Initial submission deadline } & 30 \text { August } 2019 \\ \text { Editor's decision on fit of topic and quality } & 30 \text { September } 2019 \\ \text { Peer review results } & 31 \text { January } 2020 \\ \text { Resubmission deadline } & 30 \text { April } 2020 \\ \text { Final decision } & 30 \text { August } 2020 \\ \text { Publication } & \text { End of } 2020\end{array}$

\section{References}

Bocken, N.M.P., de Pauw, I., Bakker, C., \& van der Grinten, B. (2016). Product design and business model strategies for a circular economy. Journal of Industrial and Production Engineering, 33, 308-320. doi:10.1080/21681015.2016.1172124

Bocken, N.M.P., Ritala, P., \& Huotari, P. (2017). The Circular Economy: Exploring the Introduction of the Concept Among S\&P 500 Firms. Journal of Industrial Ecology, 21, 487-490. doi:10.1111/jiec.12605

Bocken, N.M.P., Short, S.W., Rana, P., \& Evans, S. (2014). A literature and practice review to develop sustainable business model archetypes. Journal of Cleaner Production, 65, 42-56. doi:10.1016/j.jclepro.2013.11.039

Boons, F., \& Lüdeke-Freund, F. (2013). Business models for sustainable innovation: state-of-the-art and steps towards a research agenda. Journal of Cleaner Production, 45, 9-19. doi:10.1016/j.jclepro.2012.07.007

de Jesus, A., \& Mendonça, S. (2018). Lost in Transition? Drivers and Barriers in the Eco-innovation Road to the Circular Economy. Ecological Economics, 145, 75-89. doi:10.1016/J.ECOLECON.2017.08.001

Evans, S., Vladimirova, D., Holgado, M., Van Fossen, K., Yang, M., Silva, E.A., \& Barlow, C.Y. (2017). Business Model Innovation for Sustainability: Towards a Unified Perspective for Creation of Sustainable Business Models. Business Strategy and the Environment, 26, 597-608. doi:10.1002/bse.1939

Ghisellini, P., Cialani, C., \& Ulgiati, S. (2016). A review on circular economy: the expected transition to a balanced interplay of environmental and economic systems. Journal of Cleaner Production, 114, 11-32. doi:10.1016/j.jclepro.2015.09.007

Hansen, E.G., Grosse-Dunker, F., \& Reichwald, R. (2009). Sustainability Innovation Cube - A Framework To Evaluate Sustainability of Product Innovations, SSRN. Imperial College Press. doi:10.2139/ssrn.1440338

Kirchherr, J., Reike, D., \& Hekkert, M. (2017). Conceptualizing the circular economy: An analysis of 114 definitions. Resources, Conservation and Recycling, 127, 221-232. doi:10.1016/J.RESCONREC.2017.09.005 
Korhonen, J., Honkasalo, A., \& Seppälä, J. (2018). Circular Economy: The Concept and its Limitations. Ecological Economics, 143, 37-46. doi:10.1016/J.ECOLECON.2017.06.041

Lewandowski, M., \& Mateusz (2016). Designing the Business Models for Circular Economy-Towards the Conceptual Framework. Sustainability, 8, 43. doi:10.3390/su8010043

Lüdeke-Freund, F. (2010). Towards a Conceptual Framework of "Business Models for Sustainability.” Rochester, NY.

Lüdeke-Freund, F., Carroux, S., Joyce, A., Massa, L., \& Breuer, H. (2018a). The sustainable business model pattern taxonomy - 45 patterns to support sustainability-oriented business model innovation. Sustainable Production and Consumption, 15, 145-162. doi:10.1016/J.SPC.2018.06.004

Lüdeke-Freund, F., Gold, S., \& Bocken, N.M.P., (2018b). A Review and Typology of Circular Economy Business Model Patterns. Journal of Industrial Ecology, in press. doi:10.1111/jiec.12763

Perey, R., Benn, S., Agarwal, R., \& Edwards, M. (2018). The place of waste: Changing business value for the circular economy. Business Strategy and the Environment, 27, 631-642. doi:10.1002/bse.2068

Richardson, J. (2008). The business model: an integrative framework for strategy execution. Strategic Change, 17, 133-144. doi:10.1002/jsc.821

Schaltegger, S., Freund, F.L., \& Hansen, E.G., (2012). Business cases for sustainability: the role of business model innovation for corporate sustainability. International Journal of Innovation and Sustainable Development, 6, 95. doi:10.1504/IJISD.2012.046944

Schaltegger, S., Hansen, E.G., \& Lüdeke-Freund, F. (2016a). Business Models for Sustainability: Origins, Present Research, and Future Avenues. Organization \& Environment, 29, 3-10. doi:10.1177/1086026615599806

Schaltegger, S., Ludeke-Freund, F., \& Hansen, E.G. (2016b). Business Models for Sustainability: A CoEvolutionary Analysis of Sustainable Entrepreneurship, Innovation, and Transformation. Organization \& Environment, 29, 264-289. doi:10.1177/1086026616633272

Stahel, W.R., \& Reday-Mulvey, G. (1981). Jobs for tomorrow: The potential for substituting manpower for energy, 1st Ed. ed. Vantage Press, New York.

Stubbs, W., \& Cocklin, C. (2008). Conceptualizing a "Sustainability Business Model.” Organization \& Environment, 21, 103-127. doi:10.1177/1086026608318042

Zucchella, A., \& Previtali, P. (2018). Circular business models for sustainable development: A "waste is food" restorative ecosystem. Business Strategy and the Environment, in press, doi:10.1002/bse.2216 